\title{
Stock-based compensation plan: an analysis of the determinants of its use u $^{\star}$
}

\author{
Marcelo Daniel Araujo Ermel ${ }^{1}$ \\ (D) https://orcid.org/0000-0002-0988-2324 \\ Email: ermel@usp.br \\ Vanessa Medeiros ${ }^{2}$ \\ (D) https://orcid.org/0000-0002-7884-8584 \\ Email: vanmedeirosufrn@gmail.com
}

${ }^{1}$ Universidade de São Paulo, Faculdade de Economia, Administração e Contabilidade, Departamento de Administração, São Paulo, SP, Brazil
${ }^{2}$ Universidade Federal do Rio Grande do Norte, Centro de Ciências Sociais Aplicadas, Departamento de Ciências Contábeis, Natal, RN, Brazil

Recieved on 02.26.2018 - Desk acceptance on 03.20.2018 - 4th version approved on 01.17.2019 - Ahead of print on 04.29.2019

Associate Editor: Fernanda Finotti Cordeiro Perobelli

\begin{abstract}
This study's aim was to investigate the main aspects that determined the use of the stock-based compensation model and the variables that influence the amount paid. The article fills the gap in the previous debate regarding the variables that affect the decision to offer stock-based remuneration, as well as revealing the factors that impact its magnitude and providing a more robust statistical treatment with regards to endogeny. Brazil is known to be a country where the agency conflict between controlling and minority shareholders predominates, and so it is important to understand the determinants of adoption and of the amount paid to managers using stock options, since remuneration can be used as a form of tunneling. This study identified a possible trade-off between cash and stock compensation, in view of increased company indebtedness. It also found that in the Brazilian market this type of remuneration is not related to governance and performance. A panel data regression was used with fixed effects in the firm and industry*year to eliminate the possible bias arising from constant heterogeneities in time for the firms and shocks in the industries in a particular year. In addition, to identify the determinants, we used a logistic regression with panel data and fixed effect in industry ${ }^{*} y e a r$. The study sample comprised 287 companies listed on the Bolsa, Brasil, Balcão (B3) exchange. This research shows that $40 \%$ of the companies in the period from 2010 to 2016 adopted stock-based compensation plans; however, the amount paid is still low, at $0.03 \%$ of total company assets. The results indicate that in the Brazilian market variables such as investment opportunities and company size increase the likelihood of adopting the employee stock options plan (ESOP). In addition, regarding the amount paid, this is negatively related to company leverage, indicating that in possible liquidity shocks the companies opt to compensate managers with shares to reduce their exposure to systematic risks.
\end{abstract}

Keywords: agency theory, employee stock option plans, ESOP, determinants, Brazilian market.

Correspondence address

Marcelo Daniel Araujo Ermel

Universidade de São Paulo, Faculdade de Economia, Administração e Contabilidade, Departamento de Administração

Avenida Professor Luciano Gualberto, 908 - CEP: 05508-010

Cidade Universitária - São Paulo - SP - Brazil

* Article presented at the XVI Brazilian Finance Conference, Rio de Janeiro, RJ, Brazil, July 2016. 


\section{INTRODUCTION}

In the current competitive environment, companies are dedicating more and more attention to potential internal instability factors, such as human resource management, conflict of interests, and the need to motivate employees (Manzoor, 2012; Shin \& Konrad, 2017). This process gains an even more important connotation in the field of publicly-traded companies, in which the separation between shareholders and managers tends to cause problems such as information asymmetry, the search for self-satisfaction to the detriment of satisfying the hiring party, and a divergence in interests between agent and hirer (Jensen \& Meckling, 1976).

Thus, many tools have been created with the intention of mitigating the effects derived from the agency conflict. It is in this context that the stock-based compensation plan, more commonly known as the employee stock options plan (ESOP), has been constituted as one of the main instruments for incentivizing agents with the aim of mitigating conflicts of interest in the internal organizational environment (Jensen, Murphy \& Wruck, 2004).

However, as shown by La Porta, Lopes-de-Silanes, and Shleifer (1999) and La Porta, Lopes-de-Silanes, Shleifer, and Vishny (2000), the predominant agency conflict in the Brazilian market is the type II conflict, between controlling shareholder and minority shareholder. Controlling shareholders will use strategies to divert the organization's resources in order to benefit themselves, such as selling company assets at low cost to other companies only they own, hiring services from their own companies at above-market prices, or granting loans and other operations, as shown by Johnson, La Porta, Lopez-de-Silanes, and Shleifer (2000), who call practices such as these "tunneling".

Wang and Xiao (2011) highlight the possibility of tunneling via executive pay, because firms with a higher propensity for this practice would have the manager remuneration and compensation packages less sensitive to performance. Thus, in environments with a high shareholder concentration and the type II conflict, corporate performance may not be determinant for the implementation of stock-based payment, nor influence the amount paid to managers (Wang \& Xiao, 2011).

In light of the above, this article has two aims: (i) to investigate what the determinants are for the use of stock-based compensation plans; and (ii) to investigate what the factors are that influence the amount paid in the form of stock-based remuneration. Both objectives refer to the companies listed on the Bolsa, Brasil, Balcão (B3) exchange in the period from 2010 to 2016.

The data were collected from the reference forms, the accounting statements, and the management reports of the companies analyzed and can be found on the B3 website and in the Comdinheiro database. The sample was restricted to 315 companies for the basic model and 287 with the data available needed to estimate the determinants of stock-based remuneration.

To achieve the objective of this study, a panel data linear regression was used with the presence of firm fixed effects to control for the constant unobserved heterogeneity in time and industry ${ }^{\star}$ year fixed effects to control for common demand shocks to the industry in year $t$, and for the determinants of stock-based payment a logistic regression was used with panel data and fixed effects in the industry and year (Gormley \& Matsa, 2013).

This study is warranted because of the growing importance of executive pay and the consequent alignment of interests between directors and shareholders. The importance of carrying out this research in the Brazilian setting lies in it being an emergent economy; the characteristics of governance in the country, such as the type I agency conflict, between shareholder and management, and the type II agency conflict, between majority shareholder and minority shareholder (La Portaet al., 1999; La Porta et al., 2000); as well as the high shareholder concentration in the Brazilian market, as shown by Ermel and do Monte (2018).

In addition, this study makes advances by investigating the effects of controlling shareholder concentration and the accumulation of the roles of chairman of the board and chief executive officer (CEO) on the decision to offer stockbased pay, as well as investigating the factors that influence the amount paid in stock-based compensation and, thus, we verify possible sensitivity between remuneration and performance, since executive pay may be a possible way of tunneling resources (Urzúa, 2009). Also with regards to the innovation and relevance of the research, in which the authors' knowledge is important, this is the first Brazilian study to investigate these effects on the stockbased amount paid to managers.

Regarding the study's first objective, the findings indicate that an increase in investment opportunities within the firm, as well as an increase in size, raises the probability of paying the managers using stocks. In relation to the second, the stock-based amount paid is 
intrinsically linked to a higher Tobin's Q; that is, there is a positive correlation between investment opportunities and the value received by the managers. In addition, a positive correlation was also observed between company leverage and stock-based pay; thus, this result suggests that when faced with possible liquidity problems more indebted firms increase the value paid to their managers with stocks, possibly to avoid the use of cash.
Besides this introduction, this article is divided into five sections. The second involves the literature review, in which the main theoretical aspects of stock-based compensation plans are discussed, also carrying out an empirical review of the literature that addresses the determinants of the adoption of ESOPs. The third explains the methodology used in the research, the fourth carries out the descriptive and econometric analysis of the results, and finally there are the main conclusions of the study.

\section{THOERETICAL ASPECTS OF THE STOCK-BASED COMPENSATION PLAN}

The stock-based compensation plan, more commonly known as ESOP, emerged in the United Kingdom and the United States between 1950 and 1960, as a way of granting agents, via contracts, the right to buy stocks for a previously established price during a previously established period (Murphy, 1999). Hall (2000) highlights that stock options for executives configure options to buy in which an agent acquires the right to purchase stocks based on a particular price. Also according to Hall (2000), the main objective of the ESOP is to link executive pay to company performance, making the executives perceive that the incentive will only occur if the entity performs well. Otherwise, if the company incurs financial losses, they will also participate in the process.

It is within this context that the ESOP lies. The growing use of this instrument, especially from the 1990s onwards, is explained by a number of important aspects. According to Hall and Murphy (2003), the main argument in favor of stock-based compensation plans is that they incentivize agents to act in accordance with shareholder interests, especially as they link these agents' pay to share price performance. Regarding this aspect, in an older study, Hall and Murphy (2002) demonstrate that the ESOP creates incentives for executives to take measures that favor share price increases, as well as avoiding measures that reduce share prices.

Concerning these positive aspects, some studies weave criticisms of this stock-based compensation model. Authors such as Yermack (1995) draw attention to the potential power of agents to manipulate data and information, demystifying the thesis that the ESOP creates incentives for executives to act in accordance with shareholder interests. For Delves (2004), the ESOP configures a problem for two basic reasons: (i) high share concessions in the hands of executives, which tends to promote risk taking on the part of these agents vis-à-vis profit maximization, leading to financial problems for the companies; and (ii) it is an ineffective instrument for combatting the agency problem.

In Brazil, as highlighted by Nunes and Marques (2005), the use of this instrument dates back to the 1970s, greatly due to the U.S. companies installed in the country. Also according to the authors, the adoption of this mechanism has risen in recent years in the country, and is regulated by article 168 of Law n. 6,404, of December $15^{\text {th }}$ of 1976 , which describes the possibility of paying agents using stock options plans. It is worth mentioning that the Accounting Pronouncements Committee (CPC) also regulates the adoption of stock-based plans, via CPC 10 (CPC, 2010), highlighting procedures for recognizing and disclosing in accounting statements stock-based payment transactions carried out by the entity.

\subsection{Determinants of Stock-Based Compensation: Previous Studies}

In the literature, a number of important articles are found that have addressed the determinants of the use of ESOPs. It is worth mentioning that the word "adoption" is used interchangeably in the international literature for firms paying stock-based remuneration for the first time in their history, as well as for companies that pay it one year, do not pay it the next, then pay it again in the following year. Yermack (1995), for example, analyzed the determinants of the use of stock options for CEOs from 792 U.S. companies in the 1984-1991 period. The author tested nine hypotheses and found only three statistically significant results. The first is that, in regulated industries, such as public sector companies, there is a lower probability of stock options being used. The second is that companies tend to use greater stock option incentives when accounting profit is composed of large quantities of noise (accruals, especially discretionary). The third is the positive relationship between liquidity constraints and 
the use of stock options; that is, the companies analyzed that suffered from liquidity problems were more likely to modify their remuneration system from one based on cash salaries and bonuses to the stock-based model.

Subsequently, Ding and Sun (2001) developed a study with the aim of identifying the determinants for the adoption of the ESOP in Singapore and measuring the impact of this adoption on shareholder wealth, based on 263 firms from the country in the period from 1992 to 1995. Specifically concerning the first aim of the study, that is, the determinants for ESOPs, the authors found that the firms' growth opportunities, represented by the market-to-book variable, has a positive relationship with the use of stock options. They also verified that the further a company's net income is from its target, the greater the likelihood of using stocks. Finally, they identified that the lower the interest coverage ratio, the greater the probability of the companies using these plans. The authors also carried out robustness tests for the determinants of ESOPs if companies from the financial sector were excluded. The results converged with those found previously, only with the inclusion of the logarithm of total assets as a proxy for company size. The results found indicate that smaller companies are more likely to adopt ESOPs.

Along the same lines as Ding and Sun (2001), Kato, Lemmon, Luo, and Schallheim (2005) examined the introduction of 562 stock options used by 344 different companies between June of 1997 and December of 2001, in Japan, paying special attention to the costs and benefits of adopting these instruments. Despite the broad focus of the study, the authors concentrated on analyzing the determinants of ESOPs in the Japanese firms, considering for methodological purposes only 316 of the 344 initial companies. The results reveal that factors such as growth opportunities, dividend payments, firm size, and return on assets are positively related with the probability of adopting ESOPs. In contrast, aspects such as company leverage and ownership structure are negatively related with the adoption of ESOPs.

Also for Japan, Uchida (2006) analyzed the determinants of the use of ESOPs in a sample of 782 Japanese companies between 1997 and 2002. It is worth mentioning that, of this universe, only 109 received approval to use stock options. The main results found by the author show that factors such as leverage and dividend payments have a negative relationship with the probability of adopting ESOPs, while firm size, growth opportunities, and degree of independence have a positive relationship.

Tzioumis (2008) analyzed the determinants of introducing the ESOP in U.S. firms in the 1994-2004 period. Among the results found, on one hand it stands out that the rotativity of CEOs in a firm increases the probability of that company using the ESOP. In addition, the firm's risk was also statistically significant and had a positive sign. On the other hand, CEO shareholder participation, his/her age, and public sector companies presented a negative relationship with the probability of adopting the ESOP. The author also applied a robustness test with the intention of confirming the results. The results converged with those found previously, with the exception of shareholder returns, which was shown to be significant at the $10 \%$ level and had a positive sign, of Tobin's Q, which was revealed to be significant at the $5 \%$ level and had a negative sign, and of public sector firms, which, in the robustness test, did not show statistical significance.

Chourou, Abaoub, and Saadi (2008) analyzed the economic determinants of the use of ESOPs for 196 companies from Canada between 2001 and 2004. In this study, the authors used two dependent variables: (i) the ratio between the annual value of the stock options and the cash compensation; and (ii) the intensity of the stock option incentives. For the first, the results showed a positive relationship with growth opportunities and firm size and a negative relationship with leverage, CEO age, CEO shareholding, and large blockholding shareholders. For the second, a positive relationship was found for "noise" in the measurement of accounting performance and a negative one was found for CEO shareholding and blockholders.

Avallone, Quagli, and Ramassa (2014) sought to identify the effect of implementing International Financial Reporting Standards 2 (IFRS 2) and of the recent financial crisis over the adoption of the stock options model in 1,555 Italian companies in the 2000-2009 period. Regarding the focus on these two factors, it should be mentioned that the authors also used other more traditional variables, such as alignment of incentives, liquidity constraints, tax benefits, and growth opportunities. The authors found that the obligation to follow IFRS 2 did not reduce the adoption of ESOPs by the Italian companies investigated. In contrast, the financial crisis, as was to be expected, resulted in a reduction in the use of this model. With regards to growth opportunities, a positive correlation with increased stock options use was verified, which also occurred in the test of the alignment of incentives variable. Finally, liquidity constraints and tax benefits showed less significance with respect to the use of ESOPs.

Luo (2015) investigated the economic determinants of the use of 225 stock options in 212 different Chinese companies between January of 2006 and June of 2013. The results reveal that company size, dividends, and three types of company ownership - when it is under manager control, under private control, and under external investor 
control - are negatively associated with the use of stock options. Regarding company ownership, the study also showed that state companies, which are quite common in China, are less likely to use these plans. In contrast, the author identified that factors such as market-to-book and previous share return presented a positive correlation with remuneration based on stock options, but only for those that go to senior managers. Finally, it was verified that total risk and non-systematic risk increase the probability of implementing such plans, while systematic risk reduces this likelihood.

Analyzing the Brazilian case, Dias (2010) sought to identify the factors that determined stocks being used in the form of remuneration in 237 companies in 2009. Regarding the variables that were shown to be statistically significant, capital concentration and industry regulation presented a negative relationship with the use of stock options, while firm size, growth opportunities, and foreign shareholder participation in the companies revealed a positive relationship.

In another study, Kaveski, Vogt, Degenhart, Hein, and Scarpin (2015) sought to analyze the factors that determined stock-based compensation for the directors of companies listed on the B3 in the period from 2010 to 2012. It is worth highlighting that only 27 companies formed part of the sample, which may be explained by the scarcity of Brazilian companies that pay their executives using stock options and by the independent variables chosen by the authors to develop the study, namely: (i) return on total assets; (ii) market-to-book; and (iii) total revenue. Of these variables, all were shown to be statistically significant, but only market-to-book revealed a positive relationship with stock-based remuneration.

Finally, there is the study from Moura, Padilha, and Silva (2016), which sought to identify the determining factors for the adoption of stock options plans in 158 publicly-traded Brazilian companies, in the period from 2009 to 2012. Breaking the results down by periods, the authors found that factors such as current liquidity, in the period from 2010 to 2012, the horizon problem, in the period from 2009 to 2012, and shareholder participation, in 2012, showed statistical significance and a positive relationship, and could be considered determinants for the adoption of stock options plans.

Table 1

Summary of the main empirical studies involving stock-based compensation

\begin{tabular}{|c|c|c|c|}
\hline Authors/year & Sample & Metrics & Results \\
\hline $\begin{array}{l}\text { Yermack } \\
\text { (1995) }\end{array}$ & $\begin{array}{l}792 \text { U.S. companies in the } \\
\text { period from } 1984 \text { to } 1991\end{array}$ & $\begin{array}{l}\text { Regulation; accounting } \\
\text { profit; liquidity constraint. }\end{array}$ & $\begin{array}{l}\text { Positive relationship for accounting profit and liquidity } \\
\text { constraint in relation to using stock options and an inverse } \\
\text { relationship for the regulation variable. }\end{array}$ \\
\hline $\begin{array}{l}\text { Ding and Sun } \\
(2001)\end{array}$ & $\begin{array}{l}262 \text { firms form Singapore } \\
\text { in the period from } 1992 \\
\text { to } 1995\end{array}$ & $\begin{array}{l}\text { Market-to-book; profit } \\
\text { target; interest coverage; } \\
\text { firm size. }\end{array}$ & $\begin{array}{l}\text { Positive relationship between the use of stock options and the } \\
\text { variables market-to-book, profit target, a lower interest coverage } \\
\text { ratio, and smaller companies. }\end{array}$ \\
\hline $\begin{array}{l}\text { Kato et al. } \\
(2005)\end{array}$ & $\begin{array}{l}562 \text { stock options } \\
\text { granted by } 344 \text { different } \\
\text { companies between June } \\
\text { of } 1997 \text { and December } \\
\text { of } 2001\end{array}$ & $\begin{array}{l}\text { Growth opportunity; } \\
\text { dividend payments; } \\
\text { firm size; ROA; debt; } \\
\text { ownership structure. }\end{array}$ & $\begin{array}{l}\text { Growth opportunity, dividend payments, firm size, and return } \\
\text { on assets are positively related with the probability of adopting } \\
\text { ESOPs. In contrast, aspects such as company leverage and } \\
\text { ownership structure are negatively related with the adoption of } \\
\text { ESOPs. }\end{array}$ \\
\hline Uchida (2006) & $\begin{array}{l}782 \text { Japanese companies } \\
\text { between } 1997 \text { and } 2000\end{array}$ & $\begin{array}{l}\text { Debt; dividend payments; } \\
\text { firm size; growth } \\
\text { opportunity; degree of } \\
\text { independence. }\end{array}$ & $\begin{array}{l}\text { Leverage and dividend payments have a negative relationship } \\
\text { with the probability of adopting ESOPs, while firm size, growth } \\
\text { opportunities, and the degree of independence have a positive } \\
\text { relationship. }\end{array}$ \\
\hline $\begin{array}{l}\text { Tzioumis } \\
(2008)\end{array}$ & $\begin{array}{l}909 \text { U.S. companies in the } \\
\text { period from } 1994 \text { to } 2004\end{array}$ & $\begin{array}{l}\text { CEO rotativity; firm } \\
\text { risk; CEO shareholder } \\
\text { participation; CEO age; } \\
\text { public sector companies. }\end{array}$ & $\begin{array}{l}\text { Positive relationship between both CEO rotativity and firm risk } \\
\text { and the probability of the company adopting ESOPs; in contrast, } \\
\text { CEO shareholder participation, CEO age, and public sector } \\
\text { companies presented a negative relationship with the probability } \\
\text { of adopting ESOPs. }\end{array}$ \\
\hline $\begin{array}{l}\text { Chourou et al. } \\
(2008)\end{array}$ & $\begin{array}{l}196 \text { companies in the } \\
\text { period from } 2001 \text { to } 2004\end{array}$ & $\begin{array}{l}\text { Growth opportunity; } \\
\text { firm size; leverage; CEO } \\
\text { age; CEO shareholder } \\
\text { participation; and large } \\
\text { blockholding shareholders. }\end{array}$ & $\begin{array}{l}\text { Positive relationship with growth opportunities and firm size and } \\
\text { negative relationship with leverage, CEO age, CEO shareholder } \\
\text { participation, and large blockholding shareholders. }\end{array}$ \\
\hline $\begin{array}{l}\text { Avallone et al. } \\
(2014)\end{array}$ & $\begin{array}{l}155 \text { companies in the } \\
\text { period from } 2000 \text { to } 2009\end{array}$ & $\begin{array}{l}\text { IFRS implementation; } \\
\text { financial crisis; alignment } \\
\text { of incentives; liquidity } \\
\text { constraints; tax benefits; } \\
\text { growth opportunity. }\end{array}$ & $\begin{array}{l}\text { The obligation of IFRS } 2 \text { did not reduce ESOP adoption. In } \\
\text { contrast, the financial crisis resulted in a reduction in the use } \\
\text { of this model. Regarding growth opportunity and alignment of } \\
\text { incentives, a positive correlation was verified with increased } \\
\text { stock option plan use. Liquidity constraint and tax benefits were } \\
\text { shown to be less significant with regard to the use of ESOPs. }\end{array}$ \\
\hline
\end{tabular}


Table 1

Cont.

\begin{tabular}{|c|c|c|c|}
\hline Authors/year & Sample & Metrics & Results \\
\hline Luo (2015) & $\begin{array}{l}212 \text { Chinese companies } \\
\text { from January of } 2006 \text { to } \\
\text { June of } 2013\end{array}$ & $\begin{array}{l}\text { Company size; } \\
\text { dividends; types of } \\
\text { ownership; market-to- } \\
\text { book; previous share } \\
\text { return. }\end{array}$ & $\begin{array}{l}\text { The company size, dividends, and ownership type variables } \\
\text { are negatively related with the use of stock options. Market- } \\
\text { to-book and previous share returns presented a positive } \\
\text { correlation with remuneration based on stock options, but only } \\
\text { for those going to senior managers. }\end{array}$ \\
\hline Dias (2010) & 237 companies in 2009 & $\begin{array}{l}\text { Capital concentration; } \\
\text { industry regulation; firm } \\
\text { size; growth opportunity; } \\
\text { foreign shareholder } \\
\text { participation. }\end{array}$ & $\begin{array}{l}\text { The capital concentration and industry regulation variables } \\
\text { presented a negative relationship with the use of stock } \\
\text { options, while the firm size, growth opportunity, and foreign } \\
\text { shareholder participation variables revealed a positive } \\
\text { relationship. }\end{array}$ \\
\hline $\begin{array}{l}\text { Kaveski et al. } \\
(2015)\end{array}$ & 27 companies & $\begin{array}{l}\text { ROA; market-to-book; } \\
\text { total revenue. }\end{array}$ & $\begin{array}{l}\text { All the variables were shown to be statistically significant, } \\
\text { but only market-to-book revealed a positive relationship with } \\
\text { stock-based remuneration. }\end{array}$ \\
\hline $\begin{array}{l}\text { Moura et al. } \\
(2016)\end{array}$ & $\begin{array}{l}158 \text { publicly-traded } \\
\text { Brazilian companies in } \\
\text { the period from } 2009 \text { to } \\
2012\end{array}$ & $\begin{array}{l}\text { Current liquidity; horizon } \\
\text { problem; shareholder } \\
\text { participation. }\end{array}$ & $\begin{array}{l}\text { The variables were shown to be statistically significant } \\
\text { and with a positive relationship, and could be considered } \\
\text { determinants for the adoption of stock options plans. }\end{array}$ \\
\hline
\end{tabular}

$C E O=$ chief executive officer; $E S O P=$ employee stock options plans; IFRS = International Financial Reporting Standards.

Source: Elaborated by the authors.

There is a conflicting situation between the previous studies: Yermack (1995) and Ding and Sun (2001) find a positive relationship between company leverage and the probability of paying managers with shares, but Kato et al. (2005) and Uchida (2006) find a negative relationship; in relation to investment opportunities, Ding and Sun (2001), Kato et al. (2005), and Uchida (2006) perceive a positive and significant relationship, however for Tzioumis (2008) this relationship is inverted. For this reason, this study will also focus on the variables already studied in the literature by using a more robust econometric method and, in addition, taking advantage of the Brazilian institutional environment to provide evidence regarding an emergent market.

Moreover, we add new possible determinants not used in previous studies, such as chair duality, since CEO duality may be a sign of possible manager dominance over company decisions (Morck, 2007) and, thus, CEOs could decide their own remuneration. In addition, we also add the percentage of the company under the controller's power after considering possible control pyramids, thus seeking to monitor the probability of the controller expropriating the minority shareholders (Wang \& Xiao, 2011).

\section{METHODOLOGICAL PROCEDURES}

To gather and analyze the variables, remuneration and performance data were collected from reference forms, accounting statements, and management reports. These data were found on the B3 website and in the Comdinheiro database. The universe of the research was composed of all publicly-traded companies listed on the B3, corresponding to 330 firms. The table with the sectors and correlations between the variables is in the appendix (Table A1).

However, after collecting the reference form information - needed to obtain the information on stock-based compensation plans - and the data relating to the companies' economic-financial performance, collected from the Comdinheiro database and the accounting statements, the sample was restricted to 315 companies for the basic model and 287 with data available needed to estimate the complete model in the six years of the study.

It is worth mentioning that the analysis covered 2010 to 2016, a period that includes the first year of the obligations - both for the companies to publish reference forms and adopt the international accounting rules - and runs up to the year all the data needed to fulfill the methodological aims of this study were available. 


\subsection{Econometric Model}

With the aim of identifying how much the variables analyzed in this study interfere in stock-based payment, model 1 will be estimated considering two different dependent variables. First, it will be estimated considering the amount paid based on stocks over total company assets; second, it will be estimated how each variable interferes in the probability of a company using employee stock options plans, by estimating the following model:

$$
\begin{aligned}
\operatorname{REM}_{i, t}=\beta_{i, t} & +\beta_{1} \mathrm{ROA}_{i, t}+\beta_{2} \text { Tobin's }_{i, t}+\beta_{3} \text { Chairduality }_{i, t}-\beta_{4} \% \text { Independents }_{i, t} \\
& -\beta_{5} \text { Book Leverage }_{i, t}+\beta_{6} \operatorname{Ln}(\text { Assets })_{i, t}+\% \text { Controller }_{i, t}
\end{aligned}
$$

in which REM will, in the first stage, be considered the total paid based on stocks / total assets and, in the second, it will be a binary variable with the value 1 if the company has made a payment based on stocks in period $t, R O A$ (return on assets) is the ratio between operating profit and total assets, Tobin's $Q$ is the sum of market value and debt over total assets, Chairduality is a binary variable with the value 1 if the $\mathrm{CEO}$ also occupies the chairman of the board position, \% Independents is the ratio between the number of independent members and the quantity of members on the board, Book Leverage is the division of total debt by total assets, $\operatorname{Ln}$ (Assets) is the proxy for company size, and finally, \% Controller is the percentage of company shares in the controller's power. Table 2 shows the specification of the variables used by this study, the previous studies that have worked with them, and their expected signs.

\section{Table 2}

Summary of the independent variables used and their respective expected signs in the estimation of the stock-based

\begin{tabular}{|c|c|c|c|}
\hline Variable & Form of measurement & Previous studies & Expected sign \\
\hline REM & $\begin{array}{c}\text { Total paid based on stocks/total } \\
\text { assets }\end{array}$ & & \\
\hline REM & $\begin{array}{c}1 \text { for stock-based remuneration } \\
\text { and } 0 \text { otherwise }\end{array}$ & $\begin{array}{c}\text { Yermack (1995), Ding and } \\
\text { Sun (2001), Kato et al. (2005), } \\
\text { Uchida (2006), Chourou et al. } \\
\text { (2008), Tzioumis (2008), Dias } \\
\text { (2010), Avallone et al. (2014), } \\
\text { Kaveski et al. (2015), Luo (2015), } \\
\text { Moura et al. (2016). }\end{array}$ & \\
\hline$R O A$ & Operating profit/total assets & $\begin{array}{c}\text { Kato et al. (2005), Kaveski et al. } \\
\text { (2015). }\end{array}$ & $+/-$ \\
\hline Tobin's Q & $\begin{array}{l}\text { (Equity value }+ \text { debt)/ } \\
\text { total assets }\end{array}$ & $\begin{array}{c}\text { Kato et al. (2005), Uchida } \\
\text { (2006), Chourou et al. (2008), } \\
\text { Tzioumis (2008), Dias (2010), } \\
\text { Avallone et al. (2014). }\end{array}$ & + \\
\hline Chairduality & $\begin{array}{l}1 \text { if the CEO is also the chairman } \\
\text { of the Board and } 0 \text { otherwise }\end{array}$ & & + \\
\hline$\%$ Independents & $\begin{array}{l}\text { Number of independents/ } \\
\text { size of the Board }\end{array}$ & Uchida (2006). & - \\
\hline Book Leverage & Total liabilities/total assets & $\begin{array}{c}\text { Yermack (1995), Kato et al. } \\
\text { (2005), Uchida (2006), Chourou } \\
\text { et al. (2008), Avallone et al. } \\
\text { (2014). }\end{array}$ & - \\
\hline $\operatorname{Ln}$ (Assets) & Logarithm of total assets & $\begin{array}{c}\text { Ding and Sun (2001), Kato et al. } \\
\text { (2005), Uchida (2006), Chourou } \\
\text { et al. (2008), Dias (2010), Luo } \\
\text { (2015). }\end{array}$ & + \\
\hline$\%$ Controller & $\begin{array}{l}\text { Percentage of company shares in } \\
\text { the controller's power }\end{array}$ & & - \\
\hline
\end{tabular}
remuneration model

$C E O=$ chief executive officer .

Source: Elaborated by the authors. 
Regarding $R O A$, there is an undefined relationship, since the variable can behave positively, demonstrating that the company is in a good financial situation, which presupposes that the interests between shareholders and managers are aligned due to the use of the incentive. In contrast, this variable can also behave negatively; that is, the lower the ROA, the more companies will use stock options aiming to generate incentives for their executives to act in improving their performance.

A positive relationship is expected in the Tobin's $Q$ variable, given that the company is investing in new profitable projects, providing a greater opportunity for growth. Thus, the more future investment opportunities the company presents, the greater the quantity of resources that it will need to capture, stimulating the practicing of better mechanisms for aligning interests between shareholders and managers, vis-à-vis greater efforts from executives in the ventures. A positive relationship is also expected in the Chairduality variable, given that the chief executive tends to raise remuneration if he/she is head of the Board, considering his/her decision-making power and level of influence in the entity, thus tending to remunerate him/herself.

In the \% Independents variable, it is undefined: the greater the degree of Board independence, the lower the probability will be of stock-based remuneration, depending a lot on the employment of greater control and monitoring in relation to the use of employee stock- based plans or on a Board with greater independence using stock options to align incentives.

In the context of the Book Leverage variable, the probability of using a stock-based remuneration model is expected to be negatively related with its level of debt. In this case, leverage works as a liquidity constraint, meaning there is greater monitoring by banks, therefore negatively impacting the level of stockbased remuneration used, and that a highly leveraged company opts to use options for remuneration due to lower cash levels.

For the $L n$ (Assets) variable, a positive relationship is expected, given that as company size increases, its difficulties in monitoring management actions also increase. Thus, the bigger the company, the greater the possibility of it having stock-based remuneration.

Finally, a positive relationship is expected between the variable relating to the percentage in the hands of the controller and the probability of using stock options. In other words, a company that presents a lower percentage of shares in the controller's power tends to give greater decision-making power and more autonomy to the agents, meaning they are able to use this instrument more for self-remuneration. In addition, as different percentages of company shares can give different incentives for the expropriation of minority shareholders, we control for the percentage of firm ownership in the controller's power.

\section{RESULTS ANALYSIS}

\subsection{Descriptive Analysis}

Table 3 provides the description of the data tabulated by company between 2010 and 2016, with the mean, standard deviation, and minimum and maximum value of the variables. Of the total companies analyzed, $40 \%$ of them used stock-based compensation plans. Based on the study from Dias (2010), there is a 7\% increase in relation to 2009 . Regarding the amount paid in stocks, this value remains low, representing only $0.03 \%$ of the company's total assets in payments.

Concerning the $R O A$ variable, measured by the ratio between operating profit and total assets, the companies presented a mean $R O A$ of $4.19 \%$. The standard deviation was higher than the mean, which shows the heterogeneity of the sample.
In 2011, the mean Tobin's $Q$ for the firms was 1.07, revealing that the companies' market value is a little above their accounting value.

In relation to the Chairduality variable, $13 \%$ of the companies analyzed presented a CEO who was also the president of the organization.

In the case of the \% Independents variable, which represents the proportion of independents on the Board of Directors and, therefore, who do not form part of the company's workforce, the proportion of independents on the boards has a mean of $18 \%$.

Analyzing the Book Leverage variable, measured by the ratio between total liabilities and total assets, a mean value of $22 \%$ is verified; that is, the average company in the sample uses third-party funding to finance $22 \%$ of its 
assets. This result is in line with Kato et al. (2005), Uchida (2006), Chourou et al. (2008), and Avallone et al. (2014).

The penultimate variable refers to the logarithm of total assets, $\operatorname{Ln}$ (Assets), used as a proxy for company size. The companies presented a mean in log of 21 , that is, average total assets of 1 billion reais.
The final variable consists of the percentage of shares in the hands of the controller. The data reveal that, on average, $62 \%$ of total shares are in the hands of the controller, revealing a high concentration in the Brazilian market.

Table 3

Descriptive statistics

\begin{tabular}{|c|c|c|c|c|c|}
\hline Variable & Obs. & Mean & Standard deviation & Min. & Max. \\
\hline $\begin{array}{l}\text { Remuneration in } \\
\text { stocks/total assets (\%) }\end{array}$ & 2,508 & 0.0377 & 0.114 & 0 & 0.761 \\
\hline Based on stocks & 2,733 & 0.405 & 0.491 & 0 & 1 \\
\hline Tobin's Q & 2,129 & 1.076 & 0.972 & 0.0403 & 5.672 \\
\hline$R O A(\%)$ & 2,726 & 3.927 & 10.13 & -46.69 & 46.62 \\
\hline Chairduality & 2,733 & 0.136 & 0.343 & 0 & 1 \\
\hline$\%$ Independents & 2,675 & 0.188 & 0.210 & 0 & 1 \\
\hline Book Leverage & 2,733 & 0.224 & 0.184 & 0 & 0.647 \\
\hline Ln(Assets) & 2,733 & 21.54 & 2.183 & 14.47 & 27.31 \\
\hline$\%$ Controller & 2,271 & 62.17 & 23.18 & 16.04 & 100 \\
\hline
\end{tabular}

Source: Own elaboration based on data from the Reference Form and Comdinheiro.

\subsection{Econometric Analysis}

To evaluate the factors that affect the magnitude of payment in stocks in the companies listed on the B3, model 1 was estimated with the dependent variable, the total paid in stock-based remuneration over total assets. The main results found are presented in Table 4.

The results reveal that only Tobin's $Q$ and Book Leverage were statistically significant and have a positive and negative relationship with the amount of stock-based remuneration, respectively. However, the governance, performance, and size variables did not present statistical significance, so they cannot be considered as factors estimated in the amount paid as stock-based remuneration.

In the case of the Tobin's $Q$ variable, given a positive variation in growth opportunities within the same company [remembering the presence of fixed effects in the firm; all the coefficients can be interpreted as a variation within the same individual, that is, in the company (Angrist \& Pischke, 2008)], better instruments are needed for aligning interests between shareholders and managers. This is something that also involves the requirement to monitor the agent's actions, given the difficulties, in firms with growth potential, to verify whether the executives are acting to promote the most profitable projects. Another explanation could be the possibility of using a greater incentive for executives to take advantage of these opportunities. This variable was shown to be statistically significant at the $1 \%$ level and had a positive sign even in the presence of the other variables, revealing that a one percentage point increase in investment opportunities is associated with a $0.02 \%$ increase in the amount paid based on stocks, that is, presenting a positive relationship with the level of stock options used. The results found are consistent with the studies from Kato et al. (2005), Uchida (2006), Chourou et al. (2008), Tzioumis (2008), Dias (2010), and Avallone et al. (2014).

With relation to Book Leverage, this variable was also significant at $1 \%$, but had a negative sign, indicating that a one percentage point increase in leverage is associated with a $0.11 \%$ fall in the proportion of stock-based remuneration. These results are coherent with the studies from Kato et al. (2005) and Uchida (2006). 
Table 4

Determinants of the amount of stock-based remuneration in the companies listed on the Bolsa, Brasil, Balcão (B3) in the 20102016 period

\begin{tabular}{|c|c|c|c|c|c|c|}
\hline & (1) & (2) & $(3)$ & $(4)$ & $(5)$ & (6) \\
\hline & \multicolumn{6}{|c|}{ Remuneration in stocks/total assets } \\
\hline \multirow{2}{*}{ Tobin's Q } & $0.036^{* * *}$ & $0.035^{* * *}$ & $0.031^{* *}$ & $0.023^{* * *}$ & $0.024^{* * *}$ & $0.022^{* * *}$ \\
\hline & $(0.013)$ & $(0.013)$ & $(0.013)$ & $(0.008)$ & $(0.008)$ & $(0.008)$ \\
\hline \multirow{2}{*}{$R O A$} & -0.000 & -0.000 & -0.000 & -0.001 & -0.001 & -0.001 \\
\hline & $(0.001)$ & $(0.001)$ & $(0.001)$ & $(0.001)$ & $(0.001)$ & $(0.001)$ \\
\hline \multirow{2}{*}{ Chairduality } & & 0.002 & 0.000 & 0.003 & 0.004 & 0.007 \\
\hline & & $(0.011)$ & $(0.011)$ & $(0.011)$ & $(0.010)$ & $(0.010)$ \\
\hline \multirow{2}{*}{$\%$ Independent } & & -0.020 & -0.010 & 0.013 & 0.009 & 0.008 \\
\hline & & $(0.026)$ & $(0.027)$ & $(0.024)$ & $(0.024)$ & $(0.024)$ \\
\hline \multirow{2}{*}{ Book Leverage } & & & $-0.086^{* *}$ & $-0.125^{* * *}$ & $-0.123^{* * *}$ & $-0.112^{* * *}$ \\
\hline & & & $(0.038)$ & $(0.040)$ & $(0.041)$ & $(0.038)$ \\
\hline \multirow{2}{*}{ Ln(Assets) } & & & -0.010 & -0.012 & -0.014 & -0.016 \\
\hline & & & $(0.008)$ & $(0.009)$ & $(0.010)$ & $(0.010)$ \\
\hline \multirow{2}{*}{$\%$ Controller } & & & & -0.000 & -0.000 & -0.000 \\
\hline & & & & $(0.000)$ & $(0.000)$ & $(0.000)$ \\
\hline \multirow{2}{*}{ Constant } & 0.002 & 0.007 & 0.256 & 0.294 & 0.348 & $0.405^{*}$ \\
\hline & $(0.013)$ & $(0.013)$ & $(0.184)$ & $(0.198)$ & $(0.220)$ & $(0.222)$ \\
\hline Firm FE & Yes & Yes & Yes & Yes & Yes & Yes \\
\hline Year FE & No & No & No & No & No & No \\
\hline Industry*Year & No & No & No & No & Yes & Yes \\
\hline Observations & 2,028 & 2,021 & 2,021 & 1,707 & 1,707 & 1,707 \\
\hline R-squared & 0.045 & 0.046 & 0.059 & 0.064 & 0.074 & 0.133 \\
\hline $\begin{array}{l}\text { Number of } \\
\text { companies }\end{array}$ & 315 & 315 & 315 & 287 & 287 & 287 \\
\hline
\end{tabular}

Notes: Robust standard deviations in parentheses.

$F E=$ fixed effects.

***, $* *, *$ statistically significant at 1,5 , and $10 \%$, respectively.

Source: Own elaboration based on data from the Reference Form and Comdinheiro.

One argument used is that remuneration is the result of performance in the previous year and, thus, the estimations may be biased due to simultaneity; therefore, model 1 was estimated with all the variables lagged by one period.

Table 5 reveals that some of the results remained unaltered and Tobin's $Q$ loses significance after the addition of variables referring to financial characteristics, such as leverage and size. However, even with the Industry ${ }^{\star}$ Year fixed effects, the leverage variable remained significant, indicating that the amount paid in stocks is negatively related to the company's leverage. The explanation is that an increase in a firm's indebtedness would increase exposure to systemic risk and, thus, to preserve liquidity, it opts to pay its managers with stocks to avoid spending cash (Kato et al. 2005).

Table 5

Determinants of the amount of stock-based remuneration in the companies listed on the Bolsa, Brasil, Balcão (B3) in the 20102016 period

\begin{tabular}{|c|c|c|c|c|c|c|}
\hline & (1) & $(2)$ & (3) & (4) & (5) & (6) \\
\hline & \multicolumn{6}{|c|}{ Remuneration in stocks/total assets } \\
\hline \multirow{2}{*}{ Tobin's Q } & $0.018^{* *}$ & $0.018^{* *}$ & 0.014 & 0.005 & 0.009 & 0.011 \\
\hline & $(0.009)$ & $(0.009)$ & $(0.009)$ & $(0.009)$ & $(0.009)$ & $(0.008)$ \\
\hline \multirow{2}{*}{$R O A$} & -0.001 & -0.001 & -0.001 & -0.001 & -0.001 & -0.001 \\
\hline & $(0.001)$ & $(0.001)$ & $(0.001)$ & $(0.001)$ & $(0.001)$ & $(0.001)$ \\
\hline \multirow{2}{*}{ Chairduality } & & 0.005 & 0.004 & -0.002 & -0.002 & 0.001 \\
\hline & & $(0.013)$ & $(0.013)$ & $(0.009)$ & $(0.009)$ & $(0.009)$ \\
\hline \multirow{2}{*}{$\%$ Independent } & & 0.004 & 0.010 & 0.011 & 0.010 & 0.005 \\
\hline & & $(0.028)$ & $(0.028)$ & $(0.017)$ & $(0.017)$ & $(0.018)$ \\
\hline \multirow{2}{*}{ Book Leverage } & & & -0.028 & $-0.085^{* *}$ & $-0.088^{* *}$ & $-0.092 * * *$ \\
\hline & & & (0.036) & $(0.034)$ & $(0.034)$ & $(0.034)$ \\
\hline
\end{tabular}


Table 5

Cont.

(1)

\begin{tabular}{|c|c|c|c|c|c|c|}
\hline & (1) & $(2)$ & (3) & (4) & (5) & (6) \\
\hline & \multicolumn{6}{|c|}{ Remuneration in stocks/total assets } \\
\hline \multirow{2}{*}{ Ln(Assets) } & & & -0.010 & -0.009 & -0.009 & -0.009 \\
\hline & & & $(0.007)$ & $(0.007)$ & $(0.008)$ & $(0.008)$ \\
\hline \multirow{2}{*}{$\%$ Controller } & & & & 0.000 & 0.000 & 0.000 \\
\hline & & & & $(0.000)$ & $(0.000)$ & $(0.000)$ \\
\hline \multirow{2}{*}{ Constant } & $0.020 * *$ & $0.019 *$ & 0.251 & 0.232 & 0.235 & 0.229 \\
\hline & $(0.009)$ & $(0.010)$ & $(0.156)$ & $(0.163)$ & $(0.170)$ & $(0.170)$ \\
\hline Firm FE & Yes & Yes & Yes & Yes & Yes & Yes \\
\hline Year FE & No & No & No & No & Yes & No \\
\hline Industry*Year & No & No & No & No & No & Yes \\
\hline Observations & 1,726 & 1,720 & 1,720 & 1,458 & 1,458 & 1,458 \\
\hline R-squared & 0.013 & 0.014 & 0.020 & 0.028 & 0.038 & 0.133 \\
\hline $\begin{array}{l}\text { Number of } \\
\text { companies }\end{array}$ & 306 & 305 & 305 & 273 & 273 & 273 \\
\hline
\end{tabular}

Notes: Robust standard deviations in parentheses.

$F E=$ fixed effects.

***, ${ }^{* *}, *=$ statistically significant at 1,5 , and $10 \%$, respectively.

Source: Own elaboration based on data from the Reference Form and Comdinheiro.

Table 6 reveals the estimation of the second part of the analysis, in which the dependent variable is whether the company adopts an stock-based compensation plan or not. From Table 4, it is possible to note that the use of options is positively related to investment opportunities and size. A one percentage point increase is associated with a $100 \%$ increase in the probability of an option plans being used, since a $1 \%$ increase in total assets is associated with a $47 \%$ increase in the probability of using a stock-based plan, thus corroborating the studies from Kato et al. (2005), Uchida (2006), and Chourou et al. (2008).

\section{Table 6}

Determinants of the choice of stock-based remuneration in the companies listed on the Bolsa, Brasil, Balcão (B3) in the 20102016 period

\begin{tabular}{|c|c|c|c|c|c|c|}
\hline & (1) & (2) & (3) & (4) & (5) & (6) \\
\hline & \multicolumn{6}{|c|}{ Remuneration in stocks/total assets } \\
\hline \multirow{2}{*}{ Tobin's Q } & $0.571^{* * *}$ & $0.626^{* * *}$ & $0.797^{* * *}$ & $0.768^{* * *}$ & $1.009 * * *$ & $1.069^{* * *}$ \\
\hline & $(0.204)$ & $(0.201)$ & $(0.204)$ & $(0.247)$ & $(0.266)$ & $(0.303)$ \\
\hline \multirow{2}{*}{$R O A$} & -0.003 & -0.004 & -0.005 & -0.017 & -0.015 & -0.017 \\
\hline & $(0.017)$ & $(0.017)$ & $(0.017)$ & $(0.022)$ & $(0.024)$ & $(0.028)$ \\
\hline \multirow{2}{*}{ Chairduality } & & -0.517 & -0.287 & -0.308 & -0.036 & -0.107 \\
\hline & & $(0.426)$ & $(0.423)$ & $(0.458)$ & $(0.487)$ & $(0.553)$ \\
\hline \multirow{2}{*}{$\%$ Independent } & & $2.138^{* * *}$ & $1.697^{* *}$ & $1.560^{*}$ & 1.393 & 1.137 \\
\hline & & $(0.768)$ & $(0.760)$ & $(0.946)$ & $(1.023)$ & $(1.192)$ \\
\hline \multirow{2}{*}{ Book Leverage } & & & 0.513 & -0.452 & -1.494 & -0.618 \\
\hline & & & $(1.049)$ & $(1.247)$ & $(1.388)$ & $(1.626)$ \\
\hline \multirow{2}{*}{ Ln(Assets) } & & & $0.482^{* * *}$ & $0.471^{* * *}$ & $0.434^{* *}$ & $0.478^{* *}$ \\
\hline & & & $(0.137)$ & $(0.155)$ & $(0.170)$ & $(0.194)$ \\
\hline \multirow{2}{*}{$\%$ Controlador } & & & & -0.013 & -0.015 & $-0.022 *$ \\
\hline & & & & $(0.010)$ & $(0.011)$ & $(0.012)$ \\
\hline Firm FE & No & No & No & No & No & No \\
\hline Year FE & No & No & No & No & Yes & No \\
\hline Industry*Year & No & No & No & No & Yes & Yes \\
\hline Observations & 1,809 & 1,797 & 1,797 & 1,529 & 1,529 & 1,529 \\
\hline
\end{tabular}

Notes: Robust standard deviations in parentheses. All the coefficients are set out as marginal effects.

$F E=$ fixed effects.

$* * *, * *, *$ statistically significant at 1,5 , and $10 \%$, respectively.

Source: Own elaboration based on data from the Reference Form and Comdinheiro. 
As another form of robustness, the model referring to the amount paid based on stocks was estimated using the systemic Generalized Method of Moments (GMM) methodology. In general, the results corroborate the previous methods, such as the positive relationship between Tobin's $Q$ and the amount paid; however, the numerical instability of the estimator should be take into consideration, as well as the criticism from Roberts and Whited (2013), in which the basic premise of the GMM of non-correlation between the lagged variables, for them to be used as an instrument, is not plausible for the corporate finance setting.

Thus, the most appropriate results are those obtained using ordinary least squares (OLS) estimations and fixed effects in the firm and Industry ${ }^{\star}$ Year.

Table 7

Robustness test using the systemic Generalized Method of Moments (GMM) estimation, for the 2010-2016 period

\begin{tabular}{|c|c|c|}
\hline & (1) & (2) \\
\hline & sharesTA_w & sharesTA_w \\
\hline \multirow{2}{*}{ Tobin's Q } & $0.0153^{* *}$ & $0.0186^{* * *}$ \\
\hline & $(0.00616)$ & $(0.00609)$ \\
\hline \multirow{2}{*}{$R O A$} & $-0.00118^{*}$ & -0.00136 \\
\hline & $(0.000714)$ & $(0.000910)$ \\
\hline \multirow{2}{*}{ Chairduality } & -0.00892 & -0.0122 \\
\hline & $(0.00807)$ & $(0.0110)$ \\
\hline \multirow{2}{*}{$\%$ Independent } & $0.0582^{* *}$ & $0.0704^{* * *}$ \\
\hline & $(0.0240)$ & $(0.0219)$ \\
\hline \multirow{2}{*}{ Book Leverage } & 0.0137 & -0.00942 \\
\hline & $(0.0264)$ & $(0.0278)$ \\
\hline \multirow{2}{*}{ Ln(Assets) } & -0.00298 & -0.00296 \\
\hline & $(0.00473)$ & $(0.00440)$ \\
\hline \multirow{2}{*}{$\%$ Controller } & -0.000142 & -0.000159 \\
\hline & $(0.000269)$ & $(0.000359)$ \\
\hline \multirow{2}{*}{ Constant } & 0.0553 & 0.0967 \\
\hline & $(0.114)$ & $(0.106)$ \\
\hline Firm FE & Yes & Yes \\
\hline Year FE & No & Yes \\
\hline Industry*Year & Yes & No \\
\hline Hansen Overid Test & 0.885 & 0.27 \\
\hline Observations & 1,458 & 1,458 \\
\hline Number of companies & 273 & 273 \\
\hline
\end{tabular}

Notes: Robust standard deviations in parentheses.

$F E=$ fixed effects.

***,**, ${ }^{*}$ statistically significant at 1,5 , and $10 \%$, respectively.

Source: Own elaboration based on data from the Reference Form and Comdinheiro.

\section{CONCLUDING REMARKS}

The inherent conflicts of interests present in joint-stock companies have motivated the search for mechanisms that incentivize agents to act in accordance with shareholder interests. One of these instruments, which has acquired an important connotation in the organizational setting, consists of the stock-based compensation plan. Based on the assumption that companies in Brazil have been adopting this instrument more and more, shown by the descriptive analysis, this study had two aims: (i) to investigate the main aspects that determined the use of the stock-based remuneration model; and (ii) to investigate the factors that influence the stock-based amount paid. Both objectives were achieved by analyzing data from companies listed on the B3 in the period from 2010 to 
2016, using a sample of 287 companies that trade their shares on the $\mathrm{B} 3$.

This study stands out from the others by introducing new variables into the analysis of the determinants of the adoption of stock-based compensation plans, which correspond to the existence of a CEO who is also the head of the Board of Directors and the percentage of shares in the hands of the controller. Besides investigating the factors that influence the amount paid in stocks, it provided empirical evidence for an emergent market with concentrated ownership.

The descriptive analysis identified that $43 \%$ of the companies used stock-based compensation plans; however, the value paid remains low, at $0.03 \%$ of total assets.

Thus, to achieve the first objective, a logit regression with panel data was used, seeking to find the determining aspects for stock-based compensation plans, taking seven variables as a reference: (i) Tobin's $Q$; (ii) $R O A$; (iii) Chairduality; (iv) \% Independents; (v) Book Leverage; (vi) Ln(Assets); and (vii) \% Controller. After estimating the model, the results showed that the determinants for adopting stock-based compensation plans are positively related to the firms' growth opportunities, when measured by Tobin's $Q$ and company size. The positive relationship with investment opportunities corroborates the studies from Kato et al. (2005), Uchida (2006), Chourou et al. (2008), Tzioumis (2008), Dias (2010), and Avallone et al. (2014). With regards to size, the result is in line with those found by Ding and Sun (2001), Kato et al. (2005), Uchida (2006), Chourou et al. (2008), Dias (2010), and Luo (2015).

Nonetheless, it is important to mention that this research did not find any relationship between the adoption of stock-based payment programs and variables related to corporate governance and performance.

Moreover, with regards to the second objective, using a linear regression with panel data and fixed effects in the firm and in the Industry ${ }^{\star}$ Year so as to exclude constant unobservable heterogeneities in time for the firms, as well as demand shocks or factors particular to the industry in some year, it was identified that leverage is associated with the amount paid based on stocks. One possible explanation is that the firms use this instrument at times when their cash flows are compromised and choose to remunerate their executive in stocks instead to cash; another variable associated with the amount is Tobin's $Q$, a proxy for investment opportunities, showing that an increase in the company's investment opportunities causes a greater amount received by the managers in order to align efforts and interests.

Possible explanations for these results lie in the assumptions that firms with growth potential need mechanisms that enable the alignment of interests between parties, that larger companies are more likely to use this instrument, given the difficulties of monitoring managers' actions, and that entities without a controller give more autonomy to the agents who, in turn, seek to maximize their own pay, which leads to greater use of stock options plans.

Comparing with other empirical studies, despite the previous conflicting evidence, it is important to highlight that this research supported a liquidity-preserving feature and the alignment of interests between manager and shareholder, as well as company size being a determining characteristic. Nonetheless, this research adopted fixed effects in order to control for unobservable heterogeneities, both at the firm level and for macroeconomic shocks in particular sectors.

Regarding the limitations of the study, it is important to mention that it is not causal in nature, since in order to find causality between the variables, random stockbased remuneration among and within the companies would be needed; in addition, the study is based on information about remuneration provided to the CVM by the companies, which are not audited. Moreover, some companies in this period made use of legal instruments in order not to disclose remuneration.

As a suggestion for future studies, we recommend analyzing the three types of stock-based compensation plans (at the money, out of the money, and in the money) with the aim of measuring which one promotes the greatest incentive for the employee. In addition, it is important to use different variables in order to find other determinants that explain the adoption of stock-based compensation plans. Finally, it is important to analyze the differences between companies that use stock options plans for their executives with those that do not, verifying whether these differences affect company performance.

\section{REFERENCES}

Angrist, J. D., \& Pischke, J. S. (2008). Mostly harmless econometrics: An empiricist's companion. Princeton, NJ: Princeton University.

Avallone, F., Quagli, A., \& Ramassa, P. (2014). The effects of accounting treatment and financial crisis on the stock option plans of Italian companies. Economic and Business Review, 16(1), 77-95. Retrieved from http://www.ebrjournal.net/ojs/ index.php/ebr/article/view/333.

Chourou, L., Abaoub, E., \& Saadi, S. (2008). The economic determinants of CEO stock option compensation. Journal 
of Multinational Financial Management,18(1), 61-77. doi: 10.1016/j.mulfin.2007.05.001.

Comitê de Pronunciamentos Contábeis (2010). Pronunciamento técnico CPC 10 (R1) - Pagamentos baseados em ações. Retrieved from http://www.cpc.org.br/CPC/DocumentosEmitidos/Pronunciamentos/Pronunciamento?Id=41.

Delves, D. P. (2004). Stock options and the new rules of corporate accountability: Measuring, managing, and rewarding executive performance. New York, NY: McGraw-Hill.

Dias, W. O. (2010). Remuneração variável nas empresas brasileiras: Estudo de determinantes da utilização de stock options (Master's Dissertation). Universidade Federal de Minas Gerais, Belo Horizonte. Retrieved from http://hdl.handle. net/1843/BUOS-8GDMEF.

Ding, D. K., \& Sun, Q. (2001). Causes and effects of employee stock option plans: Evidence from Singapore. PacificBasin Finance Journal, 9(5), 563-599. doi: 10.1016/S0927538X(01)00027-0.

Ermel. M. D. A., do Monte, P. A. (2018). Controle acionário, remuneração de executivos e desempenho empresarial: Evidências para o mercado brasileiro. Revista Brasileira de Finanças, 16(3), 455-491.

Gormley, T. A., \& Matsa, D. A. (2013). Common errors: How to (and not to) control for unobserved heterogeneity. The Review of Financial Studies, 27(2), 617-661.

Hall, B. J. (2000). What you need to know about stock options. Harvard Business Review, 78(2), 121-129. Retrieved from

https://hbr.org/2000/03/what-you-need-to-know-about-stockoptions.

Hall, B. J., \& Murphy, K. J. (2002). Stock options for undiversified executives. Journal of Accounting and Economics, 33(1), 3-42. doi: 10.1016/S0165-4101(01)00050-7.

Hall, B. J., \& Murphy, K. J. (2003). The trouble with stock options. Journal of Economic Perspective, 17(3), 49-70. doi: $10.1257 / 089533003769204353$.

Jensen, M., \& Meckling, W. (1976). Theory of the firm: Managerial behavior, agency costs and ownership structure. Journal of Financial Economics, 3(4), 305-360. doi: 10.2139/ssrn.94043.

Jensen, M., Murphy, K., \& Wruck, E. (2004). Remuneration: Where we've been, how we got to here, what are the problems, and how to fix them [Working Paper]. ECGI - Finance Working Paper No. 44/2004. Retrieved from https://papers. ssrn.com/sol3/papers.cfm?abstract_id=561305.

Johnson, S., La Porta, R., Lopez-de-Silanes, F., \& Shleifer, A. (2000). Tunneling. The American Economic Review, 90(2), 22-27.

Kato, H. K., Lemmon, M., Luo, M., \& Schallheim, J. (2005). An empirical examination of the costs and benefits of executive stock options: Evidence from Japan. Journal of Financial Economics, 78(2), 435-461. doi: 10.1016/j. jfineco.2004.09.001.

Kaveski, I. D. S., Vogt, M., Degenhart, L., Hein, N., \& Scarpin, J. E. (2015). Fatores determinantes da remuneração baseada em ações de empresas brasileiras. Revista de Administração da UNIMEP, 13(2), 100-116. doi:10.15600/1679-5350/rau. v13n2p100-116.
La Porta, R., Lopez-de-Silanes, F., \& Shleifer, A. (1999). Corporate ownership around the world. The Journal of Finance, 54(2), 471-517.

La Porta, R., Lopez-de-Silanes, F., Shleifer, A., \& Vishny, R. W. (2000). Agency problems and dividend policies around the world. The Journal of Finance, 55(1), 1-33.

Law n. 6,404, of December $15^{\text {th }}$ of 1976. (1976, December $\left.17^{\text {th }}\right)$. Describes Joint-Stock Companies. Retrieved from http://www. planalto.gov.br/Ccivil_03/leis/L6404consol.htm.

Luo, L. (2015). Determinants of stock option use by Chinese companies. The Journal of Applied Business Research, 31(4), 1355-1376. doi: 10.19030/jabr.v31i4.9323.

Manzoor, Q. A. (2012). Impact of employees motivation on organizational effectiveness. Business Management and Strategy, 3(1), 1.

Medeiros, V. C. D. (2015). Plano de remuneração baseado em ações: uma análise dos determinantes da sua adoção nas empresas listadas na BMґFBOVESPA (Course Conclusion Study). Universidade Federal do Rio Grande do Norte, Natal.

Morck, R. (2007). Behavioral finance in corporate governanceindependent directors and non-executive chairs. Journal of Management and Governance, 12(2), 179-200.

Moura, G. D. de, Padilha, E. S., \& Silva, T. P. da. (2016). Fatores determinantes para adoção de planos de opções de ações em companhias abertas brasileiras. Revista de Educação e Pesquisa em Contabilidade, 10(3), 272-288. doi: 10.17524/ repec.v10i3.1361.

Murphy, K. J. (1999). Executive compensation. Handbook of Labor Economics, 3, 2485-2563.

Nunes, A. de A., \& Marques, J. A. V. da C. (2005). Planos de incentivos baseados em opções de ações: Uma exposição das distinções encontradas entre as demonstrações contábeis enviadas à CVM e à SEC. Revista Contabilidade \& Finanças, 16(38), 57-73. doi: 10.1590/S1519 70772005000200006.

Roberts, M. R., \& Whited, T. M. (2013). Endogeneity in empirical corporate finance. In Handbook of the economics of finance (Vol. 2, Part A) (pp. 493-572). Amsterdam: Elsevier.

Shin, D., \& Konrad, A. M. (2017). Causality between high-performance work systems and organizational performance. Journal of Management, 43(4), 973-997.

Tzioumis, K. (2008). Why do firms adopt CEO stock options? Evidence from the United States. Journal of Economic Behavior \& Organization, 68(1), 100-111. doi: 10.1016/j.jebo.2007.06.008.

Uchida, K. (2006). Determinants of stock option use by Japanese companies. Review of Financial Economics, 15(3), 251-269. doi: 10.1016/j.rfe.2005.08.001.

Urzúa, F. (2009). Too few dividends? Groups' tunneling through chair and board compensation. Journal of Corporate Finance, 15(2), 245-256.

Wang, K., \& Xiao, X. (2011). Controlling shareholders' tunneling and executive compensation: Evidence from China. Journal of Accounting and Public Policy, 30(1), 89-100.

Yermack, D. (1995). Do corporations award CEO stock options effectively? Journal of Financial Economics, 39(2-3), 237-269. doi: 10.1016/0304-405X(95)00829-4. 


\section{APPENDIX}

\section{Table A1}

Number of companies by sector

\begin{tabular}{lcc}
\hline Sector & $\mathbf{n}$ & $\mathbf{\%}$ \\
\hline Industrial goods & 328 & 12 \\
\hline Construction and transport & 44 & 2 \\
\hline Cyclical consumption & 480 & 18 \\
\hline Non-cyclical consumption & 207 & 8 \\
\hline Financial and others & 602 & 22 \\
\hline Hotels and restaurants & 4 & 0 \\
\hline Raw materials & 262 & 10 \\
\hline Oil, gas, and biofuels & 46 & 2 \\
\hline Chemicals & 2 & 0 \\
\hline Health & 98 & 4 \\
\hline Information technology & 57 & 2 \\
\hline Telecommunications & 85 & 3 \\
\hline Public utility & 518 & 19 \\
\hline Total & 2,733 & 100 \\
\hline
\end{tabular}

Source: Elaborated by the authors.

Table A2

Correlation between the study variables

\begin{tabular}{|c|c|c|c|c|c|c|c|c|}
\hline & $\begin{array}{l}\text { Stock-based } \\
\text { remuneration }\end{array}$ & Tobin's Q & $R O A(\%)$ & Chairduality & $\begin{array}{c}\% \\
\text { Independents }\end{array}$ & $\begin{array}{c}\text { Book } \\
\text { Leverage }\end{array}$ & Ln(Assets) & $\%$ Controller \\
\hline Tobin's Q & 0.400 & & & & & & & \\
\hline ROA (\%) & 0.139 & 0.576 & & & & & & \\
\hline Chairduality & -0.0519 & -0.0382 & 0.0427 & & & & & \\
\hline$\%$ Independents & 0.223 & 0.153 & 0.0174 & -0.170 & & & & \\
\hline Book Leverage & -0.0552 & -0.00480 & -0.131 & -0.144 & 0.191 & & & \\
\hline Ln(Assets) & -0.0699 & -0.184 & 0.00470 & -0.136 & 0.202 & 0.299 & & \\
\hline$\%$ Controller & -0.106 & 0.0444 & -0.0236 & 0.0389 & -0.260 & -0.110 & -0.239 & \\
\hline $\begin{array}{l}\text { Stock-based } \\
\text { remuneration }\end{array}$ & 0.449 & 0.232 & 0.0232 & -0.0620 & 0.264 & 0.0339 & 0.0810 & -0.172 \\
\hline
\end{tabular}

Source: Elaborated by the authors. 